\title{
The Urban Dimension of the Albanian Transition Cities Was Damaged as a Result of the 'Big Government' and Not Its Absence: An Assessment in Relation to the Planning Instruments!
}

\author{
Gentian Kaprata \\ European University of Tirana
}

Abstract

Albanian inhabited cities and centres have undergone chaotic developments in the years of transition, and this has come as a result of development not based on previous territorial and urban planning. Thus, construction, urban and territorial development in the transition years has not been the result of the implementation of previously approved territorial and urban planning instruments. This has come as a result of the lack of territorial and urban plans (local or national), which would precede construction and urban development with the aim of making this development smart, sustainable and comprehensive. In this context, we have made an observation in attempt to find the reasons for the lack of territorial and urban planning instruments in relation to governance. Our concern is focused on the question: has the scope of governance been so narrow that it has left out the task of drafting and approving territorial planning instruments; or was their absence for other reasons? As will be presented in this paper, transitional governments have not lacked: neither sectoral legislation that obliges the implementation of planning instruments; nor public institutions charged by law specified by duties in this field; nor public budget funding and foreign donors for their design. In contrast, it has been the characteristics of the left 'big government' and the public irresponsibility that characterize what have hindered the drafting and adoption of territorial and urban planning instruments.

Keyword: big government, small government, classical liberalism, modern liberals, territorial and urban planning instruments.

\section{Introduction}

One of the most basic concerns of the Albanian transition society is the way in which Albanian cities have changed as a result of fragmented and unplanned development. This is a concern that affects the quality of urban life of every Albanian citizen, but even after three decades it has not been addressed from a political and governmental standpoint. In this article we are interested to understand the political and governing reason of this very unpopular product of construction and urban development of Albanian cities and inhabited centres.

In this sense, we will start with a very brief presentation of the theoretical difference between the political left and right regarding the role and extent of governance. This will give us a general understanding of the concept of 'proper government measure' according to the two poles of the political spectrum. As we will see, for contemporary liberals the 'right measure of government' is 'big government', while for classical liberals it is 'small government'. The 
difference between these two concepts lies and is expressed in three elements: the scope of legislation, public institutions and budgetary funding for performing a specific governing function.

Further, we will see how the chaotic and fragmented development of cities and other inhabited centres has come as a result of the lack of planning instruments or the widespread inadmissibility of their parties, in cases when they existed. In this context widely accepted by many authors, whom we will refer to throughout the article, we will try to assess the political and governing reasons that explain the lack of planning instruments or the widespread inadmissibility of interested parties. As we will see later, transitional governments have lacked neither sectoral legislation, nor public institutions with tasks in this sector, nor funding for the design of planning instruments.

The reason for the lack of planning instruments and the practical result of development in their absence, has not been the 'small government' of a classical liberal approach; but on the contrary, it has been the statist 'big government'. Hyper-legislation, hyper-administration and over-financing have accompanied numerous processes of drafting territorial planning instruments, but have failed to produce the appropriate and widely accepted instruments. It is these types of instruments that can ensure a smart, sustainable and inclusive development, which would provide cities and residential centres that offer a higher quality of urban life to citizens.

\section{The difference between the political left and right in the role and size of government}

After three anti-authoritarian revolutions inspired by John Locke's Second Treaty of Government, which brought the Constitutional Monarchy to Britain, American Independence and the First French Republic, the liberalism he advocated is an apotheosis of individual freedom and unequivocal contestation of authoritarianism (Locke, 2005, p. 20). Since then, classical liberalism has contributed to a constant struggle for the inalienable rights of the individual and a political system based on: legitimacy, limitation, separation and accountability of power (Locke, 2005, pp. 77-218). Many political philosophies or their application to various governments in the history of the world, have modified its principles and gone further to the ideological axis "left-right". This has happened, starting with the liberalism of the late 19th and early 20th centuries (Spencer, 2005; Friedman, 2005), or that of the late 20th and early 21st centuries with Habermas and Rolls (Fuga, 2003). For this reason, in this article, we have accepted the principles of Classical Liberalism as a benchmark through which we will assess the ways in which transitional governments in Albania have addressed territorial and urban planning issues.

The essential difference between the left and the right lies in the fact that while the left is for a large government, the right is for a small government (Spencer, 2005; Friedman, 2005; Fuga, 2003; Biberaj, 2000; Gjura, 2015; Civici, 2013; Lami, 2013). This essence of the difference between them, formulates the divisions in all other secondary aspects. The concept of "big government" defended by the left as 'government of the right measure', needs and at the same time seeks for: a broad governance scope, which reduces the role of the individual in society; concentration of governing functions in the hands of the highest level of government; extensive network of state institutions that need hyper-legislation to exercise these governing functions; and consequently high state expenditures for the administrative maintenance of these institutions, and the exercise of these functions (Friedman, 2005; Spencer, 2005; Civici, 2013). 
Some of the general notions of the left for 'big government as government of the right measure' come to us from the late 19th and early 20th century liberal approaches, which called for the expansion of governing activities. and centralization of governance functions and scope (Spencer, 2005; Friedman, 2005). As well as the Habermasian philosophy that introduced the concept of "civil rights" or "positive rights", which, being in addition to Locke's "natural rights", obviously force the government to enlarge in order to protect them, but also reducing the role of the individual at the same time. Likewise, and with the same requirements, comes the Rolls concept of "corrective law" which overlapped "liberal law" to achieve a "right to justice" (Fuga, 2003).

Whereas, the concept of "small government" that is defended by the right as 'government of the right measure', detached from Spencer's opinion, requires: "reduction of forced cooperation and expansion of voluntary cooperation... narrowing of state authority and expanding the space where every citizen can act uncontrollably... protecting individual freedoms and against coercion by the state" (Spencer, 2005, p. 19). For Locke "The power of society or of the legislature which it creates can never be presumed to extend beyond what is necessary for the common good" (Locke, 2005; p. 162). According to him, a state is obliged to govern according to stable and in force laws, proclaimed and recognized by the people and not through improvised decisions; to do justice with impartial and fair judges, who must resolve disputes through these laws; and use community force within the country only to enforce such laws (police) and abroad to protect the community from foreign attack and occupation (Locke, 2005).

If we were to refer to Friedman's approach, on the tasks of government we could quote "the basic roles of government in a free society [are]: to provide a means by which we can modify rules, to mediate differences between us in terms of ensuring the enforceability of the rules by those few who would not otherwise play the game "(Friedman, 2005, p. 29), and" its [government's] main function should be to protect our freedom, both from enemies abroad and from our fellow citizens: to maintain law and order, to guarantee the implementation of private contracts, to promote competitive markets "(Friedman, 2005, p. 2).

These definitions on the fundamental importance of individual freedom and the role of the state, also present the first task of a libertarian which is the preservation of freedom, which for Friedman "is a subtle and delicate tree" and to control the role and size of government, which according to him if not controlled can turn into a Frankenstein that destroys the freedom of the individual and the society in whose protection it was created (Friedman, 2005). Because, according to Friedman, "Government is necessary to protect our freedom, it is a means by which we can exercise our freedoms; however, because of the concentration of power in political hands, it is also a threat to freedom" (Friedman, 2005, p. 2).

While Spencer, referring to the political opinion of Jeremy Bentham, who was an English philosopher, jurist and social reformer who was considered the founder of modern utilitarianism, would underline the role of the state "Bentham tells us that the government fulfils its mission by creating rights to give individuals, the right to personal security; the right to protection of honour; the right to property" (Spencer, 2005, p. 80). So, if the government grows, in terms of increasing its role in the social sphere and the governing sphere of activity, what happens in reality is that the government 'swallows' our freedoms. This phenomenon is also distinguished by Spencer when he stated that "Unlimited power over citizens, which, quite reasonably, was attributed to a ruling individual because it was believed that he 
represented God, is now attributed to a ruling group about which no one says that represents God" further presenting the harms of not rightfully limited power and the need to limit the role and measure of government (Spencer, 2005, p. 99).

The same view is held by John Stuart Mill, in his book "On Freedom", on the need to set boundaries for government, although it may be "elected by the people and accountable," as self-government would be conceived at the time, or "the power of the people over the people themselves." For Mill, governments must be kept in check because "Like all tyrannies, the tiranny of the majority was and still is considered scary, mainly because it operates through acts of public authority" (Mill, 2005, p. 9). In short, the size and role of government should be kept in constant control, because it not only tends to reduce citizens' freedoms, but also that for this purpose, it uses public instruments and authorities, which are financed by taxpayer money. As Mill would underline, "Power itself is illogical. The best government has no more right than the worst. Power is just as harmful or more harmful when exercised in accordance with public opinion than when exercised in opposition to it" (Mill, 2005, p. 23).

\section{Territorial and urban development of the transition and lack of territorial planning instruments}

Today's Albanian cities and all territories adapted for development present a series of problems and urban imbalances which is evidently negatively affecting the quality of life of citizens (WB, 2007; Fuga, 2004, 2012; Aliaj 2008; Imami et al., 2008). There are two instruments that a government uses to exercise control over urban and territorial development, and they are: planning instruments, or different types of urban and territorial plans; and development control instruments, the most important of which is the construction permit (Faja and Alimehmeti, 1983; IHS Alumni et al., 1998; Imami et al., 2008; Faja, 2008; Aliaj, 2003, 2008). The whole process of urban and territorial development administration takes place on these two pillars, and these are the state controls, although with different names at different times, that have been established by the Albanian laws since that of 1978 (Official Gazette, no. 3, 1978) to that of 2014 (Official Gazette, no. 137, 2014). In this article we will observe the issue of urban condition of cities from the point of view of territorial and urban planning instruments.

The urbanization that included the country was the development unprecedented by the previous planning and this was one of the reasons that produced this massive damage to Albanian cities during the transition period (Misja and Misja, 2004; WB, 2007; Aliaj, 2008; Imami et al., 2008; IHS Alumni et al., 1998). In this context, IHS Alumni et al. would underline that "Insufficient planning and coordination, in the medium or long term, will result in higher costs of urban development" (IHS Alumni et al., 1998, p. 13). Governments, both central and local, failed to design planning instruments, according to their level of governance and in accordance with their governance functions (IHS Alumni, et al., 1998; Aliaj, 2008; Imami et al., 2008; WB, 2007). The World Bank in 2007 would point out that "The few master plans [planning instruments] that exist date back to the time of communism and do not meet the requirements of the time for land use and are ill-adapted to the market economy." (WB, 2007, p. 53).

Derraj would also talk about this situation in 2008 when he would underline that "in Albania at the moment it is difficult to talk about an effective administration of the territory [through previously approved plans] by the authorities as at the central level, as well as in the local one" (Imami et al., 2008, p. 52). According to Derraj, the processes of urban and territorial 
development "are based [only] on technical norms which record the distances between the facilities to be built, the allowed density, as well as what are the administrative steps that construction should follow" (Imami et al., 2008, p. 52). In short, Derraj emphasizes that development has been allowed based on certain conditions of urban design and in the absence of urban or territorial planning. While emphasizing that "the territorial development of a country should be based on plans, which are organically linked to each other" (Imami et al., 2008; p. 53).

The lack of urban and territorial plans would be presented by Fuga in 2012, when while talking about the great increase of the population in Tirana and its decline in the rest of the country, he emphasizes that the time has come "to make these policies [urban and demographic] with national and local plan" (Fuga, 2012, p. 154). Simply put, Albania of rapid economic, political, social, cultural, demographic development, and in this sense also construction, as a result of the separation from the nails of socialism of central planning, lacked throughout the years of transition the instruments of territorial planning, such as development policies, plans and regulations, which would orient this rapid development towards sustainability, but also would influence this rapid development to be both smart and comprehensive at the same time.

In support of this argument, suffice it to say that the last General Territorial Plan, then called the General Regulatory Plan of the Capital, was approved by the communist government (IHS Alumni, et al., 1998; Faja, 2008; Aliaj, 2008). It was drafted by the Institute of Urban Design in 1989 and approved on 1 February 1990 by the Government led by Prime Minister Adil Carcani (Kotmilo and Kotmilo, 2017; Aliaj, 2008). Even today, Tirana does not have a Territorial Plan to precede a comprehensive, smart and sustainable development, which will help us build another Tirana from what we have, as Aliaj would point out in 2008 "Tirana refers to to date an urban plan, which was not only drafted 20 years ago, but was conceived in the time of another system "(Aliaj, 2008, p. 106), but also IHS Alumni, et al., 1998, when they emphasized that "The existing Regulatory Plan [of Tirana], not being oriented by real objectives, could not master the development of this situation" (IHS Alumni, et al., 1998, p. 28).

Even Faja in 2008 would present that all Albanian cities were developing in the years of transition in the absence of planning, because their last plans were drafted in the years of communism (Faja, 2008). This situation of unplanned development previously planned, is identified for all major Albanian cities and is such, in the absence of planning instruments, for both levels of government (Imami et al., 2008; pp. 52-55). The central government has failed to develop territorial planning instruments in relation to the development sectors that belong to it as a field of activity, such as national infrastructure or the distribution of the population throughout the territory. In 2008, Derraj would underline that "In Albania we continue not to have a Spatial Plan at the national level" (Imami et al., 2008; p. 53).

Also, local governments have failed to draft and approve general, sectoral or cross-sectoral instruments of territorial development for the territories in their jurisdiction, or partial urban studies for their structural units, in accordance with the General Territorial Plans (Aliaj, 2008; Imami et al., 2008). In this context, Derraj would state that "Most Albanian cities (municipalities) operate with Regulatory Plans approved before the '90s" (Imami et al., 2008, p. 53). Simply put in the form of a sentence, beyond the propaganda presentations that the parties have prepared on this topic, in transition Albania there was a lack of development planning (IHS Alumni, et al., 1998, pp. 28-29; Aliaj 2008, p. 106; BB, 2007, pp. 53-54). 


\section{Lack of planning instruments and legislation, institutions and public funding for this governing function}

While the lack of planning instruments, or urban and territorial plans, is evident, and that this has produced a lot of damage to the urban and territorial dimension of the country, the question is what were the causes of their lack. Were they missing as a result of the libertarian 'small government', and in this way should we develop a left 'big government', which will provide us with the missing plans? To understand this we will return to the classics of liberalism, and specifically Spencer, who when explaining his concept of "Hyper-legislation" as a phenomenon of the 'big government', introduces hyper-legislation and hyperadministration as its characteristics. (Spencer, 2005, pp. 104-158). Both of these are associated with high costs for financing the exercise of hyper-administration activities, in the implementation of the hyper-legislation for which they were created (Friedman, 2005; Spencer, 2005).

Observed in this context, in order to blame the libertarian 'small government' for the lack of urban and territorial plans, we need to find a lack of public funding, legislation and institutions for doing so. Contrary to this scenario but in line with reality, a lot of money of Albanian, European or American taxpayers has been spent: on maintaining state institutions and agencies with specific tasks and functions in territorial planning; in national and international tenders and competitions with the aim of drafting these plans. For the drafting and approval of planning instruments, as separate projects, there was no lack of funding, part of which was funding in the form of grants or loans of international institutions (IHS Alumni, et al., 1998; Aliaj, 2008).

IHS Alumni, et al., In 1998, while talking about the need to address the unplanned development situation would introduce that "In response to this planning situation, USAID has supported a Land Management Program focused on concrete issues, including existing staff and the community as baseline data", or further "The Austrian Government was also active in preparing a Plan for Tirana" (IHS Alumni, et al., 1998, p. 29). Aliaj would present this fact more clearly, when he underlined that "Since 1989, when the last regulatory plan was approved, various donors have funded at least 7-8 planning initiatives helping to draft regulatory, strategic and specific plans for the region and the city of Tirana" (Aliaj, 2008, pp. 106-107).

Although none of these planning documents have served in practice, in most cases they have not been approved by the political authority of Albanian governments, payments for foreign or Albanian consultancy have been made (Aliaj, 2008). As Aliaj would point out, while writing on the topic of public costs for territorial planning "Without mentioning the absurd fact that the Albanian government has paid these consultations from funding such as donations or loans (in this case they must be paid through taxes), strangely it does not de jure accept the final products of this assistance, even though it has reimbursed the service money for foreign consulting firms ?!" (Aliaj, 2008, p. 107).

Only for Tirana, three instruments of general territorial planning have been financed: The plan of the administration of Mayor Rama, which failed to be approved at the final level in the National Council of Territorial Regulation of the Republic of Albania; The plan of the administration of Mayor Basha, which was drafted by the local administration in a comprehensive process, and was approved by the decision of the National Council of the Territory on February 15, 2013; and the Plan of the administration of Mayor Veliaj, which was drafted under the direction of the Italian architect Boeri, was approved by the Municipal 
Council of Tirana on December 29, 2016, and further approved by the decision of the National Council of the Territory on April 20, 2017. (National Agency for Territorial Planning [AKPT], 1993-2017).

There are few cities for which the process of drafting the Local Territorial Plan has been funded only once. Most, are the cities for which the plan has been funded more than twice. For the Tirana-Durrës Space, two funds have been provided for Spatial and Regional Studies (AKPT, 1993-2017, 2015). Coastal tourist areas, from Velipoja in Shkodra to Ksamili in Saranda, have been budgeted at least once by the Master Plan, not to mention the Kavaja Rock, Golem, Karpen, which have been paid three times for tourist planning. The South Coast from the Bay of Vlora to the Cape of Stillo, have been funded three 'Master Plans for Tourism Development and Coastal Protection', part of which have been approved by the Territorial Adjustment Council of the Republic of Albania or the National Territorial Council (AKPT, 19932017; Imami et al, 2008).

In addition to funding initiatives to design territorial planning instruments, there has been no shortage of public institutions that have been established and funded to perform planning functions. Under the Ministry of the line of the Territorial and Urban Development sector, the 'Institute of Urban Studies and Designs' (ISPU) has functioned, which has been organized and has functioned with the task of drafting National and Local planning instruments. According to Article 8 of Law 7693/1993 'On Urban Planning' (Official Gazette, 1993), but further also in Article 13 of Law 8405/1998, 'On Urban Planning', it was determined that "ISPU is the state body at the national level that drafts urban studies and designs defined in the urban planning regulation "(Official Gazette, 1998), while in chapter V of the urban planning regulation approved by VKM no. 722, dated 19.11.1998, defines the role and tasks of the ISPU, among others "ISPU is a specialized state body at the national level in the field of spatial planning and urban planning studies at the national, regional and local level" (Official Gazette, 1998 ). Following the adoption of Law 10119/2009 'On Territorial Planning and Development', the National Agency for Territorial Planning [AKPT] was established (QBZ, 2010) which performs similar tasks.

Public institutions set up and funded to exercise duties and responsibilities in the field of urban and territorial planning have also existed at the local level of government. The three laws mentioned above oblige the Local Government Units to include in its administration units with duties and responsibilities in the urban planning sector (Official Gazette, 1993, 1998; QBZ, 2010). To take the example of the municipality of Tirana, it includes in the organizational structure of its administration a General Directorate of Territorial Planning and Development, which includes four directorates with 10 sectors, and dozens of officials who are paid from taxes to perform planning tasks and territory control (Municipality of Tirana [BT], 2020).

\section{Conclusions and recommandations}

As we briefly presented earlier in this article, the lack of territorial planning instruments has not come as a lack of governance, or as we have called it because of the "small" libertarian government. The failure in planning did not come from the lack of a state, but from the leftist 'big government', which allows itself to maintain non-existent institutions and waste the public money of Albanians and the generosity of internationals, without giving any product (Aliaj, 2008). It was the leftist 'big government' with its own characteristics, such as extensive 
bureaucracy and preferential decision-making of political and administrative leaders (Spencer, 2005; Friedman, 2005), that prevented the drafting of territorial and urban planning instruments, which allowed unplanned development.

This is in line with what Aliaj would say when writing about the reasons for unplanned construction "due to the inability of post-communist governments to provide legitimate alternatives to citizens who already have a legitimate right to free movement" (Aliaj, 2008, p. 96). But, more here, the statist mentality of the public administration influences, as if Aliaj would say "To this is added the almost conservative mentality of professionals, who still today have not managed to overcome the limitations of the mentality and education of the period of centralized economy" (Aliaj, 2008, p. 96).

In contrast, a "small" and effective libertarian governance, at both levels of government, guided by modernizing, liberalizing and decentralizing approaches and principles is a need for the aim of designing, approving and implementing territorial planning instruments in comprehensive democratic processes of interested parties and affected by potential developments in the territory under study. Such governance would reduce the role of governments (central and local) in planning processes and involve citizens or interested parties in these processes. It also increases the level of democracy and empowerment of the citizen in political decision-making processes and contributes to a construction development widely accepted by all development-affected parties. Development based on planning instruments designed and adopted in a comprehensive and democratic process, provides three essential characteristics. It is sustainable, in economic, social and environmental terms; it is smart; and comprehensive with the aim of realizing the economic and political freedoms of the citizens.

Despite the modestly important conclusion we have reached in this article, it must be acknowledged that addressing this topic requires further observation. In this sense, we recommend researchers in the field of urban sociology or political science focused on public policy, to use this 'doorway' opened by this writing, to understand more on this very important issue of national and social development. We also recommend political parties, both in government and in opposition, to conduct political analysis to understand more, but also to include the modest conclusion of this article in their election or governing programs.

\section{Bibliography}

[1] National Agency for Territorial Planning, [AKPT], (1993-2017), 'Buletini i Vendimeve të KRRTRSH dhe KKT, 1993-2017', Tiranë, http://www.azht.gov.al/al/legjislacioni/legjislacioni/buletini-i-vendimeve-tekrrtrsh-kkt-1993-2017/buletini-i-vendimeve-te-krrtrsh-kkt-199320171496402173

[2] National Agency for Territorial Planning, [AKPT], (2015) 'Plani i Integruar Ndërsektorial për Zonën Ekonomike Tiranë-Durrës; Draft Konsultimi Mbi Dokumentin e Politikave', Tiranë 2015 http://www.azht.gov.al/files/pages_files/17-03-23-0220-53DRAFT_PINS_Tirane_Durres_20_06_2016.pdf

[3] Aliaj, B., (2008), 'Misteri i Gjashtë', Tiranë: shtëpia botuese Botime Afrojdit,

[4] Banka Botërore, [BB], (2007), 'Vlerësim i Sektorit Urban në Shqipëri', Tiranë, http://docplayer.net/37925061-Vleresim-i-sektorit-urban-ne-shqiperi.html

[5] Bashkia Tiranë, [BT], (2020), 'Struktura organizative', Tiranë, https://tirana.al/struktura-organizative 
[6] Biberaj, E., (2000), 'Shqipëria në Tranzicion; Rruga e vështirë drejt demokracisë', Tiranë: botimet Ora

[7] Civici, A., (2013), 'Tregu apo Shteti', Tiranë: Shtëpia Botuese UET Pres,

[8] Faja, E., (2008), 'Urbanistika; teknika dhe kompozimi', Tiranë: Ufo University Pres,

[9] Fuga, A., (2003), 'Majtaj jo djathtas', Tiranë: Botime Ora,

[10] Fuga, A., (2012), 'Rënia e Qytetit', Tiranë: shtëpia botuese Papirus,

[11] Friedman, M., (2005), 'Kapitalizmi dhe Liria', Tiranë, 2005: shtëpia botuese IPLS dhe Dita, përkthim nga Adri Nurellari,

[12] Gjuraj, T., (2015), 'Nova Demokratia', Tiranë: shtëpia botuese UET press

[13] IHS Alumni, IHS, Co-Plan, (1998), 'Qyteti i ndërtuar nga njerëzit; Ide për të menaxhuar realitetin urban në Shqipëri', Tiranë: Shtëpia Botuese Eurorilindja,

[14] Imami, A., Dhamo, S., Derraj, E., Kulluri., Lelaj, O., dhe Aliaj, B., (2008), 'Hapësira qytetare drejt fundit të tranzicionit ?!, Këndvështrime filozofike dhe teknike', Tiranë: Botime Afroidit

[15] Kotmilo, Gj., and Kotmilo, E., (2017) 'IFAU Tirana- $1^{\text {st }}$ International Forum on Architecture and Urbanism', Tiranë: Publisher faculty of Architeture and Urbanism (FAU)-Polytechnic University os Tirana (PUT)

[16] Lami, R., (2013), 'Paqartësia e strukturimit të raporteve; Parti Politike-Ideologji', Tiranë: Universiteti i Tiranës, Fakulteti i Shkencave Sociale, Departamenti i Sociologjisë , Programi i Studimit të Doktoraturës http://www.doktoratura.unitir.edu.al/wp-content/uploads/2013/12/DoktoratureRoland-Lami-Fakulteti-i-Shkencave-Sociale-Departamenti-i-Sociologjise.pdf

[17] Locke, J., (2005), 'Traktati i Dytë i Qeverisjes', Tiranë; IPSL \& Dita 2000, përkthyer nga Aleko Minga

[18] Misja, V dhe Misja, A. (2004) 'Vështrim mbi situatën e banesave në Shqipëri', Tiranë: Akademia e Shkencave e Shqipërisë,

[19] Mill, J., S., (2005), 'Mbi Lirinë', Tiranë, 2000: shtëpia botuese Julvin 2, përkthyer Gëzim Banushi dhe Luan Banushi,

[20] QBZ, (2010), 'Përmbledhëse Legjislacioni për Ndërtimet', Tiranë: botim i Qendrës së Botimeve Zyrtare, https://qbz.gov.al/preview/ba544cc3-052a-4e95-85370c7c4547c1c8

[21] Spencer, H., (2005), 'Njeriu kundër Shtetit', Tiranë: shtëpia botuese Dita 2000, përkthim nga Bashkim Shehu,

[22] World Bank, [WB], (2007), 'Albania Urban Sector Review', Tiranë, https://openknowledge.worldbank.org/bitstream/handle/10986/19622/372770E NGLISH01iew1P09932501PUBLIC1.pdf?sequence=1\&isAllowed=y 